\title{
石臼挽きそば粉の特性に及ぼす保存の影響
}

\author{
川上いずみ*§，村山伸樹，川崎貞道*，伊賀崎伴彦，林田祐樹 \\ 熊本大学大学院自然科学研究科 \\ *熊本製粉株式会社
}

\section{Influence of Storage Period on Characteristics of Stone-milled Buckwheat Flour}

\author{
Izumi Kawakami*§, Nobuki Murayama, Sadamichi Kawasaki*, \\ Tomohiko Igasaki and Yuki Hayashida \\ Department of Graduate School of Science and Technology, Kumamoto University, \\ 2-39-1 Kurokami, Kumamoto 860-8555 \\ * Kumamoto Flour Milling Co., Ltd., 1-25-1 Hanazono, Kumamoto 860-8625
}

\begin{abstract}
This study investigated the effects of storage of stone-milled buckwheat flour on its flavor and texture using sensory evaluation and instrumental analyses. Samples of stone-milled buckwheat flour were stored for 0,7 , and 14 days at $25^{\circ} \mathrm{C}$ in kraft bags and then their taste, scent, and texture were measured. The moisture content in the samples decreased with increased storage period. On taste evaluation, samples with a longer storage period had significantly higher scores for bitterness and astringency compared with the control samples that were not stored $(P<0.05$, Student's $t$-test). Moreover, instrumental analysis with taste sensors revealed significant differences in some sensor outputs relative to the storage period $(P<0.05$, Student's $t$-test). In contrast, on scent evaluation, samples with a longer storage period had lower scores, while on instrumental analysis using GC-MS, the total amount of flavor components decreased with increased storage. On texture evaluation, hardness significantly increased as the storage period increased $(P$ $<0.05$ ANOVA), while instrumental analysis using a texture analyzer revealed a decrease in elasticity with increased storage. These results showed that prolonged storage of stone-milled buckwheat flour alters its taste, scent, and texture. The instrumental analyses used in this study were valid for quantitative evaluation of such sensory changes.

(Received Nov. 4, 2008 ; Accepted Jun. 26, 2009)
\end{abstract}

Keywords : buckwheat, texture, taste, scent, storage, sensory evaluation, instrumental analysis キーワード : そば, 風味, 保存, 官能評価, 機器分析

日本の伝統食品のひとつにそば切りがあり，日本ではソ バ (Fagopyrum esculentum Moench) は年間 10 万トン以 上消費されている1)。そば切りは風味・テクスチャーが重 要視され，そばを挽いてすぐに麺に加工することが好まし いと言われるが，これは製粉後，時間の経過と共に風味・ テクスチャーが変質しやすいと考えられているためであ る2).しかしながら，これらの変化を計測する方法は官能 評価に頼る部分が大きいため客観性がそしく, 機器分析に よる計測も報告されているが223), 重要な風味を客観的に計 測した報告はない，工業的に使用するためには製粉後，保 存することが必要となり，良質なそば粉の提供には製粉 後，いかに風味を変質させないかが重要であり，そばの品 質变化を把握し，対策を講じることが必要である。そこで

干860-8555 熊本県熊本市黒髪 2-39-1

* $=860-8625$ 熊本県熊本市花園 1-25-1

$\S$ 連絡先 (Corresponding author), izumi-kawakami@bears-k.co.jp
我々は，まずそば粉の風味に対する保存温度の影響につい て官能評価および種々の機器を用いて調べ，そばの風味を 維持するには保存温度が低い方が適していることを報告し た ${ }^{4)}$. 今回は，クラフト包材に封入したそば粉の保存日数 の影響について官能評価および種々の機器で測定し，官能 評価に代わる客観的手法の可能性を検討することを目的と する．具体的には，製粉後 0 日，7 日および 14 日目のそば 粉について官能評価を行い，これと同時に同じサンプルに ついて，味覚センサ ${ }^{5) 6}$ ，ガスクロマトグラフ質量分析計お よびテクスチャーアナライザなどの機器を用いて客観的測 定を行い，これらの測定が官能評価とどのような関係にあ るのかを検討することである.

\section{実 験 方 法}

\section{1. テストサンプル}

実験には平成 17 年に収穫され, 温度 $18^{\circ} \mathrm{C}$, 湿度 $70 \%$ で 
保管された北海道産そば（キタワセソバ）を使用した。そ ばを石臼で挽砕した直後 $1 \mathrm{~kg}$ をクラフト包材に入れ， $25^{\circ} \mathrm{C}$ の条件で 14 日間保存し，保管 0 日目，7 日目，14 日目 のサンプルをテストサンプルとした。 そば粉は抜き身を石 臼で挽いた「挽きぐるみ」のそば粉であり，歩留まりは殼 の付いた状態の玄そばに対し $54 \%$ だった。

\section{2. 成分分析}

そば粉試料の基本特性を調べるため, 水分, 灰分, 蛋白 質の成分分析を行った. 水分は, $135^{\circ} \mathrm{C}$ で 2 時間乾燥し, 水 分計（DF410，ヤマト科学社）を用いて測定した。灰分は, $550^{\circ} \mathrm{C}$ で 12 時間灰化させ, 残った灰の量を測定し, サンプ リング重量に対する百分率により求めた。蛋白質は全窒素 測定器（Rapid N, ELEMETAR 社）により全窒素量を測 定し，窒素たんぱく換算係数 6.25 を乗じて求めた。また, 測定は 1 つのサンプルにつき 1 回測定した.

\section{3. 官能評価}

テストサンプルの官能評価は前報 ${ }^{4)}$ に準じ，挽砕後 0 日 のそば粉 $1 \mathrm{~kg}$ を脱酸素剂入りのガスバリア性フィルム包 材に 14 日間保管したコントロールサンプルと比較する相 対評価で行なった。コントロールサンプルを官能評価値 3.0 として, 各保存日数におけるテストサンプルの官能評 価を行なった。

(1) 味

各保存日数におけるテストサンプルのそば粉 $80 \mathrm{~g}$ を熱 湯 $100 \mathrm{~g}$ と攪拌し，そばがきを作成して味の官能評価を 行った。評価パネルは食品開発に従事し, 日常的にそばの 官能評価を行っている男女の研究員 6 名とした。評価の対 象となるそば粉を利用し，そばの味の特徵を描き出す表現 用語の収集を行い，そばを表現する評価項目 7 項目を抽出 した。評価項目は「甘味」,「渋味」,「酸味」,「苦味」,「ピ リピリ感」,「小豆味（コク）」，「ヒ工味（雑味）」の 7 項目 で，コントロールを標準点 3 点とし，1点（弱い）から 5 点 （強い）の 5 段階相対評価を用いて評価した。

(2) 香り

味の官能評価法と同様にそばがきを作成し，香りの官能 評価を行った。そばの香りに関しては，そばの特徴と考え られる「あずき様の匂い」を発する成分を「そば臭」とし て官能評価の対象とした。味覚と同様にコントロールサン プルの評価点を 3 点とし， 1 点（弱い）から 5 点（強い）の 5 段階相対評価を用いた。

(3) テクスチャー

テクスチャーの官能評価はそば粉 $80 \%$, 小麦粉 $20 \%$, 水 $30 \%$ をミキンングし, $1.2 \mathrm{~mm}$ に圧延後, 幅 $1.7 \mathrm{~mm}$ に裁断 したそば切りを作成し，3 分間茹でたそば切りを試験に供 した。評価項目は「硬さ」，「滑らかさ」の 2 項目とし，コ ントロールを標準点 3 点とし 1 点（弱い）から 5 点（強い） の 5 段階相対評価を用いて評価した。

\section{4. 味覚センサによる味分析}

味識別装置（SA402B, インテリジェントセンサテクノロ ジー社) ${ }^{5) 6)}$ を用いて，味の客観的な測定を行った。この装 置は 8 種類の脂質膜 ( $1 \mathrm{ch}$ : デシルアルコール, $2 \mathrm{ch}$ : オレイ ン酸, $3 \mathrm{ch}$ ジオクチルホスフェート $(\mathrm{C}), 4 \mathrm{ch}: \mathrm{C}: \mathrm{T}=9: 1$, $5 \mathrm{ch}: \mathrm{C}: \mathrm{T}=5: 5,6 \mathrm{ch}: \mathrm{C}: \mathrm{T}=3: 7,7 \mathrm{ch}:$ トリオクチル メチルアンモニウムクロライド $(\mathrm{T}), 8 \mathrm{ch}$ : オレイルアミン) で構成され，広域選択性をむった味センサで7)，広範囲な 食品の品質管理に利用されている ${ }^{8)}$.

まず，各温度条件で保存したそば粉 $80 \mathrm{~g}$ に熱湯 $100 \mathrm{~g}$ を 入れ，そばがきを作成した。その後，超純水で 6 倍に希釈 し，回転数 $3500 \mathrm{rpm} ， 10$ 分間の遠心分離により得られた 上清を用いて味識別装置で分析を行った。測定は味覚セン サを 90 秒洗浄後，30 秒間サンプルに浸して測定を行い，1 つの試料に対して 3 回の計測を行なった。

\section{5. ガスクロマトグラフ質量分析計（GC-MS）による香 り分析}

香り分析は固相マイクロ抽出法（SPME）を用いた。テ ストサンプル $2 \mathrm{~g}$ をバイアル瓶に入れセプタムで密閉した 後, $60^{\circ} \mathrm{C}$ で 15 分間加熱した。ヘッドスペースに SPME (SUPELCO 製) 挿入後, $60^{\circ} \mathrm{C}$ で 60 分間抽出し， GC-MS 分析に用いた. SPME は $65 \mu \mathrm{m}$ 厚さで, PDMS-DVB でコー ティングしたものを使用した。 ガスクロマトグラフ質量分 析計 (GC-17A, 島津製作所製) により分析し，ターゲット 成分のピーク面積を比較した。香りの分析は，各サンプル で 1 回行なった。

\section{6. テクスチャーアナライザによるテクスチャー分析}

テクスチャーアナライザ（TA-XT2i, SMS 社）を用い て，テクスチャー分析を行った。実験に用いたテストサン プルそば切りはテクスチャーの官能評価と同じ方法で作成 し，引っ張り試験を行った。測定試料は引っ張り専用プラ ンジャーにセットし，クリアランス $5 \mathrm{~mm} ，$ プランジャー 速度 $3 \mathrm{~mm} / \mathrm{sec}$ で麺を引っ張り，麺が破断する際の力「抗 張力」，抢よび破断するまでの時間から麺の伸びを測定し た「伸長度」を測定值として用いた。このテクスチャー分 析は各サンプルについて 5 回行なった.

\section{実 験 結 果}

\section{1. 成分分析}

表 1 に成分分析の測定結果を示した。保存日数が経過す るにつれ水分は減少し，0日目で $15.1 \%$ の水分が 14 日目 では $12.3 \%$ と減少した。

\section{2. 官能評価}

(1) 味の評価

図 $1 \mathrm{~A}$ に味に対する官能評価の結果を示す。「苦味」につ いては, 保存日数が長い程, 苦味が強くなる傾向であった。 「渋味」についても「苦味」と同様に，保存日数が長い程， 渋味が強くなっていた。一方, 「甘味」,「酸味」,「ピリピリ 
表 1 テストサンプルの保存日数による成分変化

\begin{tabular}{cccc}
\hline \hline 保存日数 & 0 日目 & 7 日目 & 14 日目 \\
\hline 水分 $(\%)$ & 15.1 & 14.2 & 12.3 \\
灰分 $(\%)$ & 1.78 & 1.88 & 1.91 \\
粗蛋白質 $(\%)$ & 11.3 & 11.3 & 11.6 \\
\hline
\end{tabular}
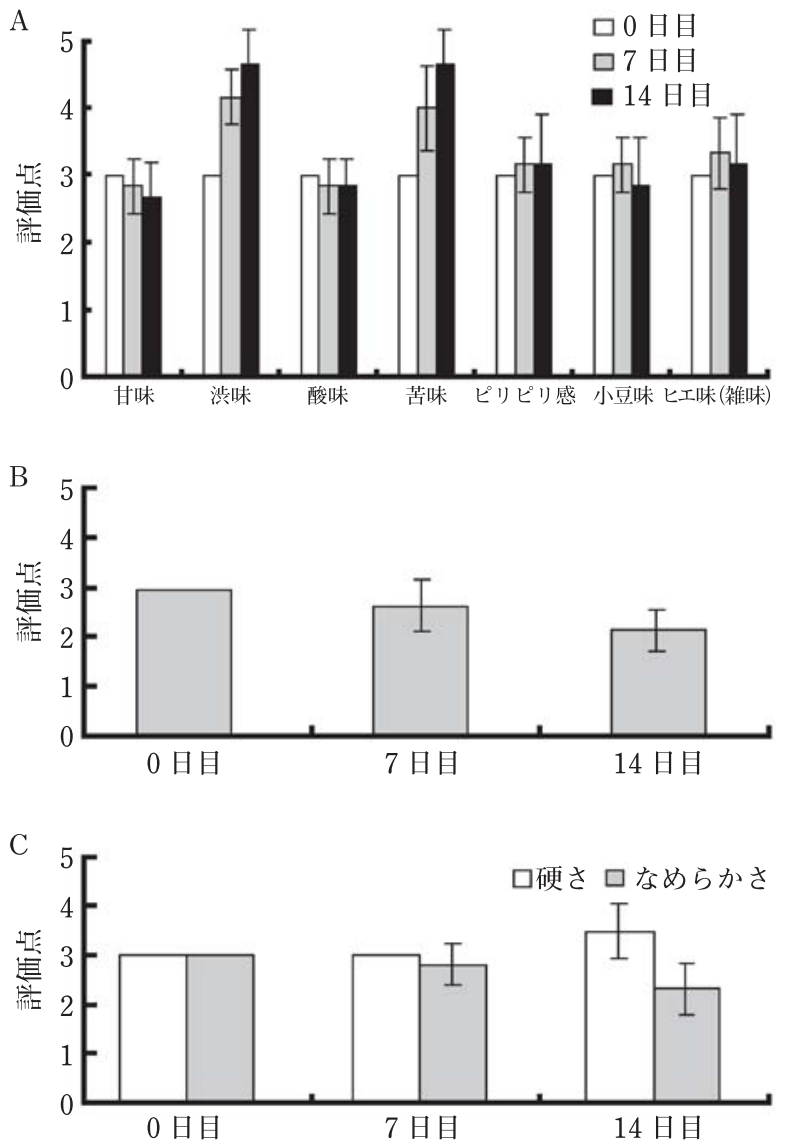

図 1 味覚, 香りおよび食感に対する官能評価

$\mathrm{A}: 6$ 人のパネリストによるそばの味覚についての平均官能 評価. B : 香りに対する平均官能評価. C : 食感に対する平均 官能評価. バーは標準偏差を表す。

感」,「小豆味（コク）」および「ヒエ味（雑味）」について はあまり変化が見られなかった。

ANOVA 解析の結果, 「苦味」および「渋味」のいずれあ 保存日数の期間に依存して有意 $(P<0.001)$ に变化するこ とがわかった. Paired $t$-testの結果, 「苦味」について各保 存日数の試料間に有意差がみられ，0日目のサンプルに対 して 7 日目および 14 日目の評価值は有意に増加していた $(P<0.003$ および $P<0.002)$. また，「渋味」についても同様 の結果で， 7 日目拉よび 14 日目の評価值は 0 日目の評価値 より屯増加していた $(P<0.05, P<0.002)$. 以上の結果か ら, そば粉は保存すると味が变化し, 特に「苦味」,「渋味」 に影響を与えることが示唆された。

(2) 香りの評価
表 2 味覚センサの出力応答

\begin{tabular}{cccc}
\hline \hline & $\begin{array}{c}\text { 日目 }(\mathrm{mV}) \\
\text { 平均 } \pm \mathrm{SD}\end{array}$ & $\begin{array}{c}\text { 昌目 }(\mathrm{mV}) \\
\text { 平均士 } \mathrm{SD}\end{array}$ & $\begin{array}{c}14 \text { 日目 }(\mathrm{mV}) \\
\text { 平均士 } \mathrm{SD}\end{array}$ \\
\hline $1 \mathrm{ch}$ & $-2.54 \pm 1.02$ & $-1.6 \pm 1.08$ & $1.91 \pm 1.15^{*}$ \\
$2 \mathrm{ch}$ & $-2.83 \pm 0.53$ & $4.47 \pm 0.70^{* * *}$ & $6.50 \pm 1.34^{* * *}$ \\
$3 \mathrm{ch}$ & $-27.76 \pm 3.15$ & $-6.20 \pm 2.62^{* *}$ & $38.55 \pm 1.95^{* * *}$ \\
$4 \mathrm{ch}$ & $-23.00 \pm 3.71$ & $-6.00 \pm 3.01^{*}$ & $30.57 \pm 3.74^{* * *}$ \\
$5 \mathrm{ch}$ & $4.68 \pm 2.44$ & $-6.93 \pm 1.25^{*}$ & $4.42 \pm 0.20$ \\
$6 \mathrm{ch}$ & $12.54 \pm 0.17$ & $-0.16 \pm 0.13^{* * *}$ & $-10.8 \pm 0.36^{* * *}$ \\
$7 \mathrm{ch}$ & $2.05 \pm 1.15$ & $-12.60 \pm 3.73^{*}$ & $-1.82 \pm 1.15^{*}$ \\
$8 \mathrm{ch}$ & $11.17 \pm 0.41$ & $-0.44 \pm 0.84^{* * *}$ & $-10.99 \pm 0.19^{* * *}$ \\
\hline
\end{tabular}

${ }^{*}: P<0.05,{ }^{* *}: P<0.01,{ }^{* * *}: P<0.001$

図1Bに香りに関しての官能評価の結果を示す，味の官 能評価と同じく日数が経つと香りが弱くなっていた。 ANOVA 解析の結果, 保存日数に依存してそばの香りが有 意 $(P<0.01)$ に減弱していることがわかった．また paired $t$-test の結果，保存日数別のサンプル間では保存日数 0 日 目の評価値に対して 14 日目の評価值は有意に減少してい た $(P<0.05)$.

(3) テクスチャーの評価

図 1C にテクスチャーに関する官能評価を示す.「硬さ」 については，7日目では官能評価は変化が見られなかった が，14 日目に評価值が高くなっていた。一方，「滑らかさ」 については，保存日数が長くなるほど徐々に評価值は減少 していた. ANOVA 解析の結果, 保存日数に依存して「硬 さ」あ「滑らかさ」あ有意に変化していることがわかった $(P<0.05)$. Paired $t$-test の結果，「硬さ」については 0 日 目の評価值に対して 14 日目の評価值は有意に大きかった が $(P<0.05)$ ，「滑らかさ」については，7 日目および 14 日 目の評価值の間に有意な差はなかった. 以上の結果から, テクスチャーについては, 14 日目のサンプルで 0 日目のサ ンプルより硬くなることが示された.

\section{3. 各種機器による分析}

(1) 味覚センサによる測定

表 2 に 8 種の味覚センサにより得られた応答出力の平均 值士SD を示した。ANOVA 解析の結果，センサ間に高度 の有意差 $(P<0.001)$ があり，保存日数に屯高度に有意差 $(P<0.001)$ が示された. Student's $t$-test の解析の結果, 全 てのセンサで統計的有意差を認めた $(P<0.05)$. 特に, $6 \mathrm{ch}$ および $8 \mathrm{ch}$ は 7 日目および 14 日目の測定值が 0 日目の測 定值に対して高度の有意差 $(P<0.001)$ を示していた.

さらに味覚センサの応答出力について, 主成分分析を 行った (図 2). 主成分 1 の寄与率は $94.05 \%$, 主成分 2 の寄 与率は $5.49 \%$ となり, 主成分 1 が寄与率の大部分であり, 味覚センサがテストサンプルを判別していることがわかっ た。 また第一主成分の固有べクトルは苦味を示す $3 \mathrm{ch}$ が $0.72,4 \mathrm{ch}$ が 0.59 と大きく（表 3)，第一主成分は日数によ 


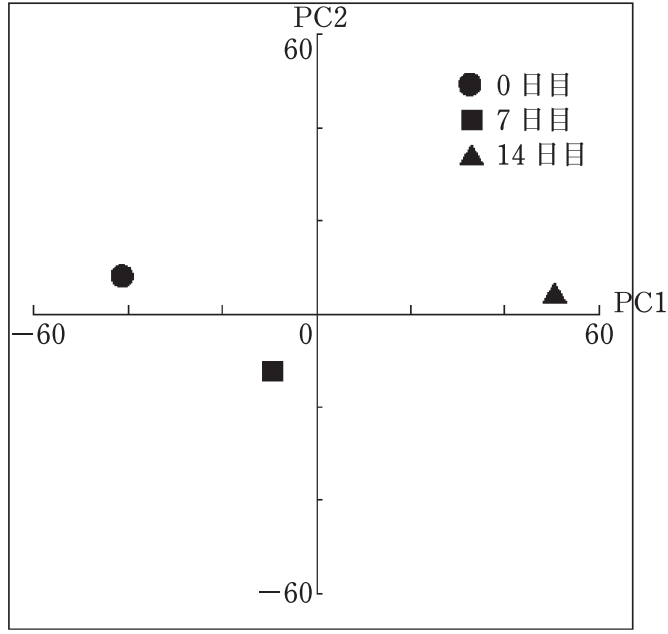

図 2 味覚センサによる主成分分析

$\mathrm{PC} 1$ : 第一コンポーネント. PC2 : 第二コンポーネント.
る苦味の増加を示していることが推察できた。

（2）ガスクロマトグラフ質量分析計 (GC-MS) による測定 GC-MS で分析により得られたクロマトグラムのマスス ペクトル（図 3A）から，そば粉に含まれる揮発性成分を推 定した。そば香気成分として報告のあるアルデヒド類, アル コール類およびナフタレン系化合物 ${ }^{9)}$ のピーク面積 (AREA) の総計量を算出し，テストサンプルの比較を行った（図 3 B). 粉砕直後のサンプルの総計量が約 $10 \times 10^{8}$ であるの之 比較し, 7 日後のサンプルで約 $1.8 \times 10^{8}, 14$ 日後は約 $1.0 \times$ $10^{8}$ と保存日数とともに減少した。検出された香気成分の 中では，青臭い㫐いとして知られる 1-Hexanol-2-ethyl と 思われる成分が保持時間 17 分に検出され, 0 日目のピーク 面積が約 $5.6 \times 10^{8}$ であるのと比較し， 7 日後のサンプルで 約 $5.3 \times 10^{6}, 14$ 日後は約 $6.2 \times 10^{6}$ と減少した.

(3) テクスチャーアナライザーによる測定

図 4 の上段に物理測定の例を示す。図より 0 日目のサン

表 3 味覚センサ出力応答の主成分分析の固有ベクトル

\begin{tabular}{lcrrrrrrr}
\hline \hline & $1 \mathrm{ch}$ & \multicolumn{1}{c}{ 2ch } & \multicolumn{1}{c}{ 3ch } & \multicolumn{1}{c}{ ch } & \multicolumn{1}{c}{$5 \mathrm{ch}$} & \multicolumn{1}{c}{$6 \mathrm{ch}$} & \multicolumn{1}{c}{ ch } & \multicolumn{1}{c}{$8 \mathrm{ch}$} \\
\hline PC1 & 0.05 & 0.09 & 0.73 & 0.59 & 0.02 & -0.24 & -0.01 & -0.23 \\
PC2 & 0.01 & -0.19 & 0.08 & 0.11 & 0.59 & 0.24 & 0.70 & 0.22 \\
PC3 & 0.07 & 0.38 & -0.57 & 0.70 & -0.08 & -0.02 & 0.09 & 0.14 \\
PC4 & 0.81 & -0.23 & -0.20 & -0.05 & 0.05 & -0.23 & 0.12 & -0.42 \\
PC5 & 0.06 & -0.21 & -0.09 & 0.20 & 0.63 & 0.21 & -0.68 & 0.02 \\
PC6 & 0.12 & 0.76 & 0.06 & -0.34 & 0.44 & -0.31 & -0.02 & 0.04 \\
PC7 & 0.56 & 0.20 & 0.29 & -0.02 & -0.24 & 0.52 & -0.11 & 0.48 \\
PC8 & 0.10 & -0.31 & 0.01 & 0.02 & -0.01 & -0.65 & -0.07 & 0.68 \\
\hline
\end{tabular}

A
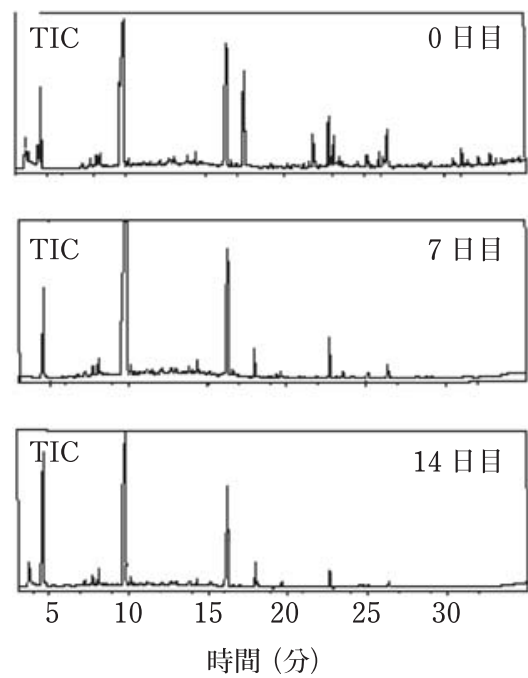

B

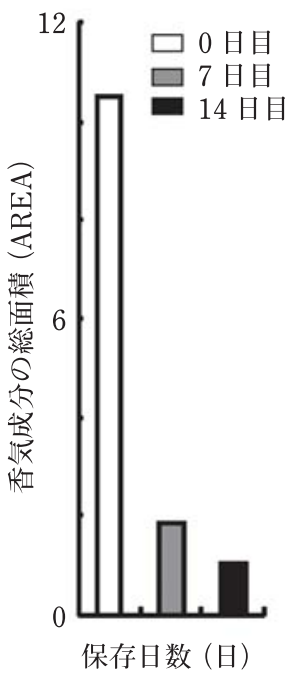

$\mathrm{C}$

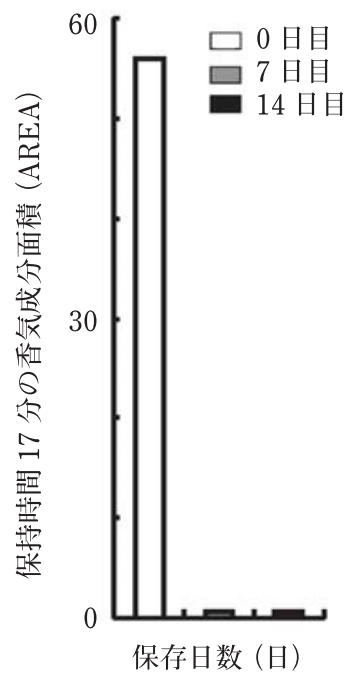

図 3 ガスクロマトグラフィー質量分析法による香気成分の測定

A : 3 分から 34 分までの成分分析の例. 上段 : 0 日目, 中段 : 7 日目, 下段: 14 日目.

$\mathrm{B}$ : 香気成分面積の総計量. $\mathrm{C}$ : 保持時間 17 分の香気成分面積 

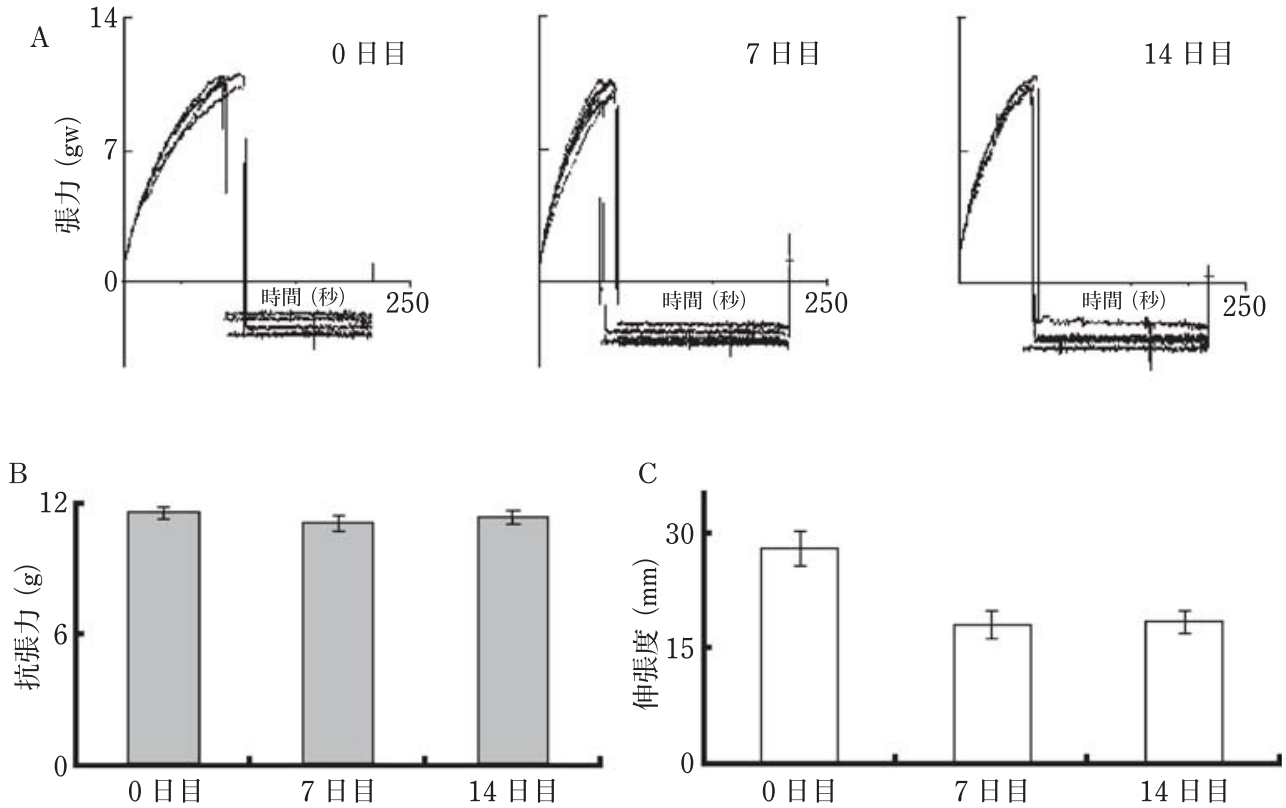

図 4 テクスチャーアナライザによる抗張力および伸張度の測定

A：0 日目，7 日目扮よび 14 日目の記録. B : 5 例の平均抗張力と標準偏差. C : 5 例の平均伸張度と標準偏差

プルに比べ， 7 日目，14 日目は明らかに伸長度が小さくなっ ていることがわかる. また図 4 の下段にそば切りの抗張力 之伸長度における 5 例の平均値を示す。抗張力は 0 日目が $11.58 \mathrm{gw}, 7$ 日目が $11.11 \mathrm{gw}, 14$ 日目が 11.39 とあまり差が なく，伸長度は 0 日目が $27.95 \mathrm{~mm} ， 7$ 日目が $18.05 \mathrm{~mm}, 14$ 日目が $18.48 \mathrm{~mm}$ となった。.ANOVA 解析の結果, 伸張度 は保存日数に依存して有意に変化したが $(P<0.001)$, 抗張 力については有意差がみられなかった. Student's $t$-test の結果, 保存日数 0 日目の測定值と比較して 7 日目掞よび 14 日目の伸張度は有意に低い值となった $(P<0.001)$.

\section{4. 官能評価と機器測定値との相関}

表 4 に「苦味」および「渋味」に対する官能評価と味覚 センサの測定值との相関を示す． $5 \mathrm{ch}$ および $7 \mathrm{ch}$ をのぞい て各センサと屯高い相関を示していた $(P<0.05, P<0.01$, $P<0.001)$.

テクスチャーの官能評価において「硬さ」については有 意差が示されたが, この「硬さ」とテクスチャーアナライザ における「抗張力」,「伸張度」および RVA 最高粘度の計 測值との相関を求めた。しかしながら，その結果は，官能 評価「硬さ」と「抗張力」との相関係数が $0.004(P>0.05)$, 同様に「伸長度」との相関が $0.09(P>0.05)$ と低い值で あった。

\section{考察}

\section{1. 成分分析}

成分分析の結果では，保存日数の経過とともに水分が减 少していることがわかり，そばの風味変化に影響を与えて いることが示唆された。 これは日数とともに水分が蒸発
表 4 官能評価（苦味・渋味）と味覚センサ出力の相関

\begin{tabular}{|c|c|c|}
\hline \multirow[b]{2}{*}{ 味覚センサー } & \multicolumn{2}{|c|}{ 官能評価 } \\
\hline & 苦味 & 渋味 \\
\hline $1 \mathrm{ch}$ & $0.58^{*}$ & $0.59^{*}$ \\
\hline $2 \mathrm{ch}$ & $0.80^{* * *}$ & $0.69^{* *}$ \\
\hline $3 \mathrm{ch}$ & $0.66^{* *}$ & $0.65^{* *}$ \\
\hline $4 \mathrm{ch}$ & $0.66^{* *}$ & $0.64^{* *}$ \\
\hline $5 \mathrm{ch}$ & 0.05 & 0.01 \\
\hline $6 \mathrm{ch}$ & $0.78^{* * *}$ & $0.71^{* *}$ \\
\hline $7 \mathrm{ch}$ & 0.17 & 0.09 \\
\hline $8 \mathrm{ch}$ & $0.76^{* * *}$ & $0.64^{* *}$ \\
\hline
\end{tabular}

${ }^{*} ; P<0.05,{ }^{* *} ; P<0.01,{ }^{* * *} ; P<0.001$

し，結果的に水分值が減少したと考えられる．水分は澱粉 の糊化特性に影響することからこれらの水分の变化は，そ ばのテクスチャーになんらかの影響を与えていることが考 えられる。

\section{2. 味の評価}

味の官能評価では，「苦味」「「渋味」でテストサンプル間 に有意差があり $(P<0.01) ， 0$ 日目と比べ 7 日目，14 日目 は評価点が高くなった。このことは日数の経過とともにそ ばの苦味，渋味が増すことを示しており，一般的に時間が 経つとそばの風味が劣るといわれることと一致している。

一方，その他の評価項目では有意差はなかった。しかしな がら，時間の経過とともにそば粉の「甘味」に対する評価 值は低下している傾向であった。また，「ヒエ味（雑味）」 についても，保存日数が経つほど，強くなる傾向にあるこ とが示唆されたが，統計的には有意ではなかった。これら 
のことから，日数経過に伴う風味の低下は，「苦味」，「渋 味」といったそばの風味としては不快を感じる味が強くな ることが原因と推察できる.

味覚センサによる測定では Student's $t$-test の解析の結 果, 全てのセンサで統計的有意差を認め $(P<0.05)$, 保存日 数によって味が変化することが示唆された. 主成分分析の 結果から，主成分 1 は日数経過に伴う苦味・渋味を示して いると考えられる。また主成分 1 は官能評価「苦味」と 0.68 , 官能評価「渋味」と 0.66 と高い相関を示した。 主成分 2 は 雑味を示す $5 \mathrm{ch}$ と 0.59 , 旨味を示す $7 \mathrm{ch}$ と 0.7 と高い固有 ベクトルを示した. $5 \mathrm{ch}$ と $7 \mathrm{ch}$ は官能評価「苦味」,「渋味」 と相関がなかったセンサであり, 官能評価では分析できな かったなんらかの味变化を捕らえていると考えられる。ま た官能評価と同様に日数経過に依存し味覚センサの応答出 力が変化していることが推察され, 味覚センサは日数経過 に伴う味の変化を測定する有効な手段であり, そばの味の 差を客観的に測定できることが示唆された。

\section{3. 香りの評価}

そばは日が経つと香りが劣るといわれるが, 香りの官能 評価で, 保存日数の経過と共に香りが減少することがわ かった。一方， GC-MS 分析ではそばの匂いを呈すると考 えられる複数の成分が検出され, それらの成分は保存日数 とともに減少することがわかった。 また保存サンプルは粉 砕直後のサンプルより揮発成分のピークが减少しているこ とがトータルイオンクロマトグラムからあ確認でき, 保持 時間 23 分の夕ーゲットの香気成分は検出されなかった。 官能評価香りと GC-MS 分析の総計量の相関を確認したと ころ, 相関係数が 0.71 と高い相関を示し, GC-MS 分析に よる香りの客観評価の可能性が示唆された。今後匂い嗅ぎ 法を用い，GC-MS で検出された成分の個々の官能評価を 行い，GC-MS とそばの香りの官能評価の相関精度を上げ ていくことが重要と考えられる.

\section{4. テクスチャーの評価}

テクスチャーの官能評価では, Paired $t$-test の結果, 「硬 さ」については 0 日目の評価值に対して 14 日目の評価值 は有意に大きかった $(P<0.05)$. 一方「なめらかさ」につい て有意差はなかったものの, 14 日目で「なめらかさ」が減 少するという評価のパネラーが多かった。いずれにせよ日 数経過により, そば切りの食感は変化することがわかっ た。

一方，テクスチャーアナライザでは「伸長度」でテスト サンプル間に有意な差がみられた $(P<0.01), 0$ 日目の平均 值で $2.28 \mathrm{~cm}, 7$ 日目で $1.77 \mathrm{~cm}, 14$ 日目で $1.52 \mathrm{~cm}$ となり 伸長度が小さくなっている，伸長度はそば切りを引っ張っ て切れるまでの時間から算出していることから, 日数経過 とと屯にそば切りは切れやすくなっておりつながりが弱く なり，あろくなっていることが推察できる.このことから， 日数経過とともにそば切りのテクスチャーが变化したこと
が確認できた。

官能評価における「硬さ」および「滑らかさ」の評価值 とテクスチャーアナライザで得られた「抗張力」および 「伸張度」の測定值との関連性を確認したところ, いずれの 項目でも高い相関は確認できなかった。 この理由として, 一つ目は, テクスチャーアナライザでは「抗張力」の変化 が無いのに対し「伸長度」の变化が著しいことから，そば 切りが硬くなっているのに加えてもろくなっていることが 想定でき，官能評価で評価した硬さと今回の伸張度の变化 とは質が異なっていることが推察された。二目は，官能 評価では硬さは 0 日目の評価值と 7 日目の評価值がほとん よ゙変化なく，14 日目に評価值が大きく变化していた。一 方，テクスチャーアナライザにおける「抗張力」は变化が 無い。また「伸長度」は 0 日目から 7 日目に顕著な減少を 示し，14 日目は 7 日目とあまりかわらない減少であった。 このようにいずれのパラメータも保存日数に依存して变化 はするが，その変化の過程が異なるために官能評価の「硬 さ」と「抗張力」および「伸張度」との相関が見られなかっ たことが考えられる. しかしながら, 別な見方をすれば, そば切りの保存日数に依存して伸張度の变化が著しいこと から，このパラメータを客観的指標に用いることができる 可能性が示唆された.

以上の結果，そばの保存日数の経過による風味・テクス チャーの变化を, 官能評価の味・テクスチャー・匂い, 機 器分析の味覚センサ・テクスチャーアナライザにより確認 でき, 従来から言われている通り, そばの風味は保存中に 变化することが明らかとなった。 また, 客観的な機器分析 （味覚センサ, GC-MS, テクスチャーアナライザ）を実施 し，これらの測定值と官能評価との相関性を一部示すこと ができた。ここで得られた知見は，そば製粉後の風味変化 を抑制する手法確立の指標として，応用できると考えられ る. 今後さらに客観的手法の精度向上のために, 味, 香り, テクスチャーに関する測定技術の向上，試験デー夕の蓄積 を行い官能評価との相関性の解析を進める必要がある.

\section{要 約}

本研究では保存日数経過にともなうそばの風味とテクス チャーの変化を官能評価と機器分析により確認し, 機器分 析による客観的手法の確立を検討した，石臼挽きそば粉を クラフト包材に $25^{\circ} \mathrm{C}$ で 14 日間 (2 週間) 保存し, 官能評価 と味覚センサ, GC-MS およびテクスチャーアナライザな どの機器分析で, 次のような知見が得られた。

（1）官能評価では保存日数の経過と共に食味が低下し, 苦味, 渋味の増加, 香りの低下, 硬さの増加が起こること が明らかとなった。

(2) 機器分析では味覚センサ, テクスチャーアナライザ によるいずれの分析でも, 保存日数経過にとむなう食味の 変化を確認できた。味覚センサでは保存日数経過による 
「苦味」,「渋味」を示唆するセンサ出力の変化が確認された $(P<0.05)$. GC-MS では香気成分の減少が確認された。テ クスチャーアナライザでは「伸長度」の減少が確認され $(P$ <0.05), 麺がもろくなっていることが示唆された.

（3）味覚センサの主成分分析の結果，主成分 1 で保存日 数の違いが示され，これは官能評価における「苦味」およ び「渋味」を示すことが推察された。すなわち，味覚セン サで保存日数によるそばの味の違いを判別できる可能性が 示唆された。

（4）そばの食味は日数経過と共に変化し, ソバ製粉後 14 日目には明らかに苦味，渋味が増加し，テクスチャーが次 第に变化し，香りも減少していくことがわかった。

\section{文献}

1）大図徳一郎, 麺業年鑑, 第 1 版, 大図徳一郎, (麺業新聞社, 東京), pp. 58-436 (2005).
2）遠山 良, 関沢憲夫, 村井一男, そば粉の保存方法に関する 研究，岩手県醇造食品試験場報告，16，153-161（1982）。

3）永田雄一，そば粉を知るための十章，そば・うどん，11，永 田雄一，(柴田書店，東京）, pp. 32-39（1982）.

4）川上いずみ，川崎貞道，村山伸樹，伊賀崎伴彦，林田祐樹， そば粉の風味に及ぼす保存温度の影響，食科工，55，559565 (2008).

5）都甲 潔，感性バイオセンサ，第 1 版，(朝倉書店，東京）, pp. 130-180 (2001).

6）都甲 潔，夢のユビキタスネットワーク社会と食のアメニ ティー，冷凍，80，18-23（2005）.

7）都甲 潔，味覚センサ，食と感性，(光琳，東京)，pp. 125221 (1999).

8）池崎秀和，おいしさの新規評価法一味覚センサの利用一 おいしさの評価技術，食品之開発，41，4-7（2006）。

9）大日方洋, 唐沢秀行, 村山 敏, 黒河内邦夫, SBSE 濃縮法 を用いたそば香気成分の分析，長野県工業技術センター食 品部報，33，58-61（2005）。

(平成 20 年 11 月 4 日受付，平成 21 年 6 月 26 日受理) 